and honorary membership of the Société Françaiso Statistique Universelle. An enthusiastic advocate of the extension of scientific knowledge, he founded popular lectures in most of the provinces of Ireland. He was interested in the application of chemistry to agriculture and wrote "An Essay on the uso of Peat or Turf, as a means of promoting the Public Health, and the Agriculture, of the United Kingdom" (1850). Among his original work in organic chemistry may be mentioned early experiments on oxymuriatic acid in 1811 and his discovery in 1836 of a hydrocarbon with the molecular formula $\mathrm{C}_{2} \mathrm{H}_{2}$. Acetylene was obtained synthetically in 1862 by Marcel Berthelot. In a letter dated January 13, 1817, Sir Humphry Davy wrote that he had received the credit for his cousin's process of improving bread by magnesia. Edmund Davy died at Kimmage Lodge, County Dublin, at the age of seventy-two.

\section{Biophysics Research at King's College, London}

THe University of London (King's College) has accepted a grant from the Rockefeller Foundation of 121,000 dollars, to be used over the next three years for research in biophysics under the general direction of Prof. J. T. Randall. The new grant marks the continuation of the Foundation's support for this field of research at King's College initiated in 1947. The grant is a recognition of the increasing importance of the contribution of biophysics to the fundamental understanding of biological processes and to the scientific basis of medicine. During the past ten voars the Wheatstone Laboratory at King's College has made outstanding contributions to our knowledge of the nucleic acid of the cell (DNA) under Dr. M. H. F. Wilkins, who is deputy director of the Biophysics Research Unit; and Prof. Randall's own group has led the way to the solution of the structure if the collagen of connective tissues and its fibrogenesis. Dr. Jean Hanson's studies (in collaboration with Dr. Hugh Huxley at University College, London) of muscle structure have developed new conceptions of the mechanism of contraction (see Nature, 173, 973; 1954). Dr. D. M. MacKay has recently been engaged on problems of visual perception (see Nature, October 26 , p. 849) which may well be of clinical value and are expected to add to existing knowledge of the working of the cerebral cortex. The Foundation's now grant will bo used to maintain and amplify the effort in all these fields of research, which havo a fundamental bearing on several important aspects of medicine.

\section{Royal Society of Arts Endowed Prizes}

The following awards have been made by the Royal Society of Arts as a result of its offer of Endowed Prizes for 1957: Howard Prize of $£ 50$ for a treatise on some aspect of the subject of motive agents to Mr. A. E. Johnson, of East Kilbride, Lanarkshire, for his work on "Turbine Disks for Jot Propulsion Units : an account of Work of the Disk Panel of the Ministry of Supply, Gas 'Turbine Collaboration Committee, during the years 1941-49"; Fothergill Prize of $£ 20$ for fire prevention or fire-fighting to Mr. P. B. Smith, of Chapel-enle-Frith, Cheshire, for his essay "A New Method of Suppressing Fires in Mines". In the opinion of the judge, this entry records the most novel suggestion that has appeared for a number of rears.
Expansion of the Imperial College of Science and Technology

The number of students at the Imperial college of Science and Technology has risen by 235 since last year and now stands at 2,450 . Since the College's expansion programme was started in 1953 the number of students has increased by 800 . The rector, Dr. R. P. Linstead, spoaking at the College's Commemoration Day ceremony held in the Royal Albert Hall on October 24, said that fifteen new professorships and readerships in the University of London have boen established and filled at the Imperial College in the past twelve months. Plans for new halls of residence are well advanced; approval has been recoived for the clearance of existing derelict properties on the south, east and part of the north sides of the Princes Gardens site to make way for the new halls (Nature, 179, 613; 1957), among which is to be Weeks Hall, for which a gift of $£ 150,000$ by Messrs. Vickers, Ltd., was announced in March.

\section{Festival of Films in the Service of Industry}

The premier award in the "Films for Use in Schools" section of this Festival, recently held in Harrogate, was won by "Mirror in the Sky"-a film intended to stimulate scientific interest among pupils of the middle-school age group. "Mirror in the Sky" was sponsored jointly by Mullard, Ltd., and the Educational Foundation for Visual Aids, and produced by Realist Film Unit, Ltd. It is part of the United Kingdom's contribution to a series of modern science films being produced by countries of Western European Union. The subject is the ionosphere and its significance in radio communication; the work of Sir Edward Appleton in proving the existence of the second, higher atmospheric layer which bears his name is outlined.

\section{Exhibition of New University Architecture}

AN exhibition of examples of new university building, admission free, will be held in the Chancellor's Hall, Senate House, University of London, during November 2-15. More than $£ 12$ million a year is at present being spent on a programme of reconstruction of universities in the United Kingdom, and it is of great importance that the new buildings should have lasting architectural merit and make a visual contribution to the education of students who live and work in them. The exhibition, which consists of photographs, plans and original drawings of university buildings in Britain and overseas, is roughly divided into soctions dealing with lay-out, science buildings and residential areas. At the end of the exhibition the scale is brought down to individual objects that explain in a more tangible way the standard of quality that should obtain throughout universities. The exhibition, which has beon arranged by the University Architecturo Exhibitions Committee with the support of the Arts Council of Groat Britain, will later visit the following university cities: Oxford (November 25-December 10), Cambridge (January), Birmingham (February), and Loeds (March).

\section{"From Coal to Coke"}

IN the Sixth Coal Science Lecture, organized by the British Coal Utilization Research Association, and given at the Institution of Civil Engineers on 